\title{
CLASSIFICATION OF INNOVATIVE METHODS USED IN HIGHER EDUCATION
}

\author{
Niyozova Yulduz \\ Teacher of the Foreign Languages Department, Karshi Engineering-Economics Institute, \\ Karshi City, Uzbekistan,
}

Article DOI: https://doi.org/10.36713/epra6043

\begin{abstract}
This article highlights the main classifications, which are used in the system of higher education. Moreover, different ideas of scientists analyzed and important points presented according to practical values.

KEYWORDS: methods, innovative, educational process, activity, terms, process, competition, research, pedagogical technology, stages, connection.
\end{abstract}

\section{INTRODUCTION}

Innovative activity in the educational process and its concepts were first studied in the works of such scientists as N.V. Kuzmina, S.M. Godnin, V.I. Zagvyazinsky, V.A Kan-Kalik, F.N. Gonobolin, V.A. Slastenin, A.I. Shcherbakov. These studies reveal innovative activities in the teaching process in terms of the dissemination of novelty and advanced pedagogical practices.

As a follower of the above-mentioned researchers, A. Haylock, N. Gross, H. Barnet, J. Basset, D. Hamilton, R. Carlson, M. Mayez, D. Chen, R. Edem management, changes in the educational process, the organization of the spread, the issues that are important for the "life and activity" of innovation were discussed.

The socio-psychological aspect of innovation in the teaching process as well as teaching methods was developed by the American researcher, scientist E. Rodgers. This scientist studies the classification of categories of participants in the process of innovation in education, its attitude to innovation.

Innovative activity of professors and teachers of higher education institutions is one of the important problems of high school pedagogy.

The word innovation means innovation, innovation, innovation.

In his research, A.I. Prigogin argues that the word innovation is based on purposeful changes that introduce new, relatively stable elements into a particular social organization, humanity, society, group. This, in turn, is an example of innovative activity.

A.I.Prigojin, B.V.Sazonov, V.S.Tolstoy, A.G.Kruglikov, A.S.Axiyezer, N.P.Stepanov and a number of other researchers divide the components of innovation processes into functional and direction: the individual micro-level of innovation and the interaction of individual innovations microsmatic.

The first round of this thoughtful approach covers a number of new ideas that have been put into practice.

In the second round of the approach, the interaction of the innovations introduced separately, their unity, competition, and, as a result, the substitution of one by another is discussed.

The scheme of the innovation process is described in the pedagogical literature. This scheme, in turn, includes the following steps:

1. The birth of an innovative idea or the creation of a concept of novelty is called the discovery phase.

2. Invention, or more precisely, the stage of innovation.

3. The ability to apply the innovation in practice is the stage of its proper use.

4. The stage of promoting the created innovation, ensuring its dissemination.

5. The dominant stage of innovation in a particular field. The novelty created at this stage loses its 


\section{EPRA International Journal of Research and Development (IJRD)}

novelty character, and an alternative form of it, which gives a perfect result, appears.

6 . The stage of narrowing the scope of the innovation by replacing the old with the new, based on the proposed new alternative.

7. The European scientist V.A. Slasten believes that the creation and introduction of innovation is a set of goal-oriented innovation creation, dissemination and use, the purpose of which is to meet the needs and aspirations of people by new means. The authors of the systemic concept of innovation (AI Prigogin, BV Sazonov, VS Tolstoy) classify new processes according to two important aspects.

\section{MATERIALS AND METHODS}

The first type involves simple, uncomplicated innovation processes. This is especially true for first-time developers.

The second round involves the development of a large-scale innovation. Innovation in a particular field is a dynamic system in which both internal logic and time are legally evolving and representing its interdependence with the environment. The concept of "new" is central to pedagogical innovation today.

In addition, there is an interest in conditional, private, local, and subjective innovation in pedagogy.

Private innovation V.A. Slastenin found that in the process of modernization involves the renewal of one of the elements of a particular system product.

Conditional innovation is a set of known situations that lead to a complex and progressive renewal process.

Local innovation is defined by the use of innovation in a particular situation, a specific object.

Another type of subjective novelty is defined as the fact that the object itself is new to a particular object.

The concepts of novelty and innovation are different in the fields of science and research.

Innovation is a tool: a new method, methodology, technology and so on.

Innovation is education: a process that develops in stages with a specific purpose.

Explaining the concept of "new", the European scientist V.I. Zagvyazinsky noted that the "new" in education is not only this idea, but also a set of unique approaches, methods, technologies that have not yet been used.

R.N. Yusufbekova, an Uzbek scholar, sees pedagogical innovation in teaching and educating as a previously unknown and previously unrecognized situation, outcome, evolving theory, and the changing content of pedagogical reality leading to practice.

This scientist R.N. Yusufbekova divides the structure of the innovation process in pedagogical innovation into three blocks:
The first block is the block of innovation in the field of pedagogy. This includes the classification of completely new pedagogical innovations in the field of pedagogy, the conditions for the creation of innovations, the norms of innovation, readiness for its adoption, development and use, tradition and innovation, the stages of innovation in pedagogy.

The second block is the block of perception, assimilation and evaluation of innovation: this includes pedagogical communities, the diversity of processes of evaluation and mastery of innovation, conservatism and innovation in pedagogy, innovation environment, readiness of pedagogical societies to perceive and evaluate new.

The third block is the block of new use and its introduction, that is, the laws and types of new introduction, use and widespread introduction.

M.M. Potashnik's interpretations of innovation processes are also noteworthy. It provides the following structure of the innovation process:

- Structure of activity - a set of motive, purpose, task, content, form, methods, methodical components;

- Subjective structure - international, regional, district, city and other levels of the subjects of innovative activity;

- Content structure - educational work, management innovation;

Emergence, development and assimilation of

- The structure of life cycles based on stages - the emergence of innovation

Presence, rapid growth, maturation, diffusion (absorption, dispersion), modernization;

- Management structure - the interaction of 4 types of management actions

Connection: planning, organization, guidance, control:

- Organizational structure - diagnostic, predictive, purely organizational,

Practical, generalizing, applying.

The innovation process consists of a system that encompasses structural structures and laws.

There are 4 main laws of the innovation process in the pedagogical literature:

- The law of ruthless instability of the environment of pedagogical innovation;

- The law of final implementation;

- The law of periodic repetition and return of pedagogical innovation;

- The law of molding (stereotyping);

\section{RESULTS AND DISCUSSION}

Today, the desire and attention to the use of interactive methods, innovative technologies, pedagogical and information technologies in the classroom is growing, one of the main reasons for this is the current situation. While traditional teaching 


\section{EPRA International Journal of Research and Development (IJRD)}

methods teach students to acquire only ready-made knowledge with a clear structure, modern pedagogical technologies allow students to search for, independently study, analyze and synthesize the acquired knowledge, and even to draw final conclusions. both teach themselves to accept. In this process, the professor-teacher provides an opportunity for the development, formation, acquisition of knowledge, as well as the upbringing of the individual, and at the same time acts as a leader, leader, mentor. This allows students to become key players in the learning process.

Therefore, the role and place of modern teaching methods, interactive methods, innovative technologies in the training of highly qualified professionals in higher education institutions and faculties is very large. Pedagogical experience, knowledge and interactive methods provide students with in-depth knowledge and skills.

Modern technologies are a pedagogical process, as well as innovations and changes in the relationship and activities of teachers and students, and in the implementation of this process, mainly innovative methods are used fully and effectively.

Interactive methods are called collective thinking, that is, methods of pedagogical influence, which are an integral part of the educational content. The peculiarity of these methods is that they are carried out only through the joint work of teachers and students.

This process of cooperation has its own characteristics, which include:

- Encourage learners not to be neglected during the lesson, to think freely, to be creative and to explore;

- Ensuring the constant interest of students in the learning process;

- To strengthen the student's interest in learning independently, creatively approaching each issue;

- The organization of constant interaction between teacher and student.

\section{CONCLUSION AND FUTURE SCOPE}

The problems of innovative and pedagogical technologies, teaching professors, practical researchers say that pedagogical technology is not only related to information technology, but also information technology, which should be used in the teaching process, distance learning. On a pedagogical basis, the technologies chosen by the teacher and the student play an important role in the joint achievement of the guaranteed result from the set goal, that is, each educational technology used in the teaching process to achieve a guaranteed result on the goal can develop collaborative activities between teacher and student, can achieve the expected positive result for both parties, can think freely in the learning process, can work creatively, can search, analyze and synthesize if they can draw their own conclusions, if they can make self-assessments, if the teacher can create opportunities and conditions for such activities, then these are the main links in the teaching process. Each topic, lesson, has a unique technology of the learning process, that is, pedagogical technology in the learning process is an individual process, which is focused on one goal, based on the needs and requirements of students, is a pedagogical process aimed at giving a pre-planned and guaranteed result.

\section{REFERENCES}

1. Ismatova.S. Problems of teaching synchron translation. SSIFL. Samarkand. 2020. P-9-15;

2. Sartre J.P. What is literature? Harvard:Harvard Univ. Press, 1988. P-9;

3. Rivers, Wilga. Teaching Foreign Language Skills. Chicago: University of Chicago Press. 1968, 60-65 p.

4. Richards, J. C., and Rogers, T. S. Approaches and methods in language teaching: A description and analysis. Cambridge: CambridgeUniversity Press. 2001, 80-83 p.

5. Brown, H. Douglas. Teaching by Principles: An Interactive Approach to Language Pedagogy, Second edition. New York: Addison Wesley Longman, Inc. 2001, P-97.

6. Halliday, M. A. K. Spoken and written language. Oxford: Oxford University Press. 1989, -31 p.

7. M. Erkinova. Audition as a method of boosting of a level in the English language. Samarkand. 2020. $P$-10-15. 